\title{
4h. 133
}

ANL/OTEC-PS-2

ANL/OTEC-PS-2

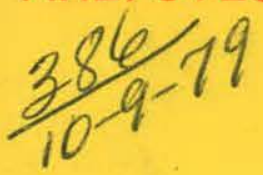

\section{OTEC Performance Tests of the Union Carbide Enhanced-Tube Condenser}

by

\author{
David T. Yung, David L. Hillis, \\ James J. Lorenz, and Norman F. Sather M/SPSP
}

Ocean Thermal Energy Conversion Program

Argonne National Laboratory

Sponsored by

U. S. Department of Energy under Contract W-31-109-Eng-38 


\section{DISCLAIMER}

This report was prepared as an account of work sponsored by an agency of the United States Government. Neither the United States Government nor any agency Thereof, nor any of their employees, makes any warranty, express or implied, or assumes any legal liability or responsibility for the accuracy, completeness, or usefulness of any information, apparatus, product, or process disclosed, or represents that its use would not infringe privately owned rights. Reference herein to any specific commercial product, process, or service by trade name, trademark, manufacturer, or otherwise does not necessarily constitute or imply its endorsement, recommendation, or favoring by the United States Government or any agency thereof. The views and opinions of authors expressed herein do not necessarily state or reflect those of the United States Government or any agency thereof. 


\section{DISCLAIMER}

Portions of this document may be illegible in electronic image products. Images are produced from the best available original document. 
The facilities of Argonne National Laboratory are owned by the United States Government. Under the terms of a contract (W-31-109-Eng-38) among the U. S. Department of Energy, Argonne Universities Association and The University of Chicago, the University employs the staff and operates the Laboratory in accordance with policies and programs formulated, approved and reviewed by the Association.

\section{MEMBERS OF ARGONNE UNIVERSITIES ASSOCIATION}

The University of Arizona Carnegie-Mellon University Case Western Reserve University The University of Chicago University of Cincinnati Illinois Institute of Technology University of Illinois Indiana University The University of Iowa Iowa State University
The University of Kansas Kansas State University Loyola University of Chicago Marquette University The University of Michigan Michigan State University University of Minnesota University of Missouri Northwestern University University of Notre Dame
The Ohio State University Ohio University

The Pennsylvania State University Purdue University Saint Louis University Southern Illinois University The University of Texas at Austin Washington University Wayne State University The University of Wisconsin-Madison

This report was prepared as an account of work sponsored by an agency of the United States Government. Neither the United States nor any agency thereof, nor any of their employees, makes any warranty, expressed or implied, or assumes any legal liability or responsibility for any third party's use or the results of such use of any information, apparatus, product or process disclosed in this report, or represents that its use by such third party would not infringe privately owned rights. Mention of commercial products, their manufacturers, or their suppliers in this publication does not imply or connote approval or disapproval of the product by Argonne National Laboratory or the United States Government.

Printed in the United States of America

Available from

National Technical Information Service

U. S. Department of Commerce

5285 Port Royal Road

Springfield, VA 22161

NTIS price codes

Printed copy: A03

Microfiche copy: A01 
OTEC PERFORMANCE TESTS OF THE UNION CARBIDE ENHANCED-TUBE CONDENSER

\author{
by \\ David T. Yung, * David L. Hillis, $\dagger$ \\ James J. Lorenz,* and Norman F. Sather \pm \\ *Components Technology Division \\ †Engineering Division \\ \pm Energy and Environmental Systems Division
}

May 1979

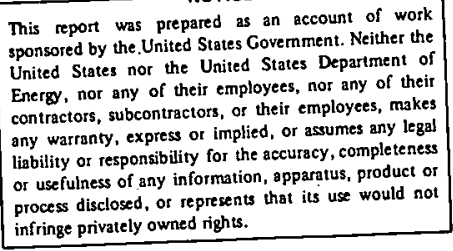
Der any of their or assumes any legal liability or responsibility for the accuracy, completeness process disclosed, of represents that its use would not infringe privately owned rights.

The Argonne Ocean Thermal Energy Conversion Program is a joint effort of the Energy and Environmental Systems Division and Components Technology Division

$$
\text { sponsored by }
$$

U.S. Department of Energy Division of Central Solar Technology 
NOMENCLATURE. . . . . ........................ . .

ABSTRACT. . . . . . . . . . . . . . . . . . ..... . 1

1 INTRODUCTION . . ....................... . . . 1

2 ENHANCED-TUBE CONDENSER. . . . . . . . . . . . . . . . . . . . . . 2

3 HEAT EXCHANGER TEST FACILITY . . . . . . . . . . . . . . . . . 5

3.1 Piping Layout . . . . . . . . . . . . . . . . . . 5

3.2. Instrumentation .. ..................... . . 7

3.3 Data Handling System. . . . . . . . . . . . . . . 7

4 OPERATING PROCEDURE. . . . . . . . . . . . . . . . . . . . . . 8

5 METHODS OF CALCULATION . . . . . . . . . . . . . . . . . . 11

5.1 Equations for the Overall Heat Transfer Coefficient . ... . . . I1

5.2 Error Analysis. . . . . . . . . . . . . . . . . . 12

6 TEST RESULTS . . . . . . . . . . . . . . . . . . . . . . . . . . 14

$6.1 \mathrm{U}_{\mathrm{o}}$ at Design Operating Conditions . . . . . . . . . . . . . . 14

6.2 Individual Heat Transfer Coefficients . . . . . . . . . . . . 14

6.3 Effect of Heat Duty on $U_{0}$. . . . . . . . . . . . . . . . 17

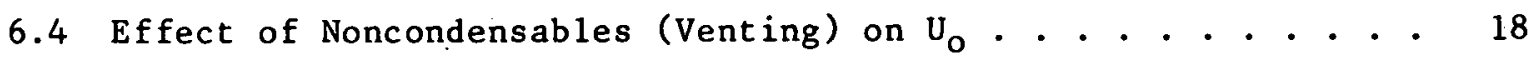

6.5 Water-Side Pressure Drop. . . . . . . . . . . . . . 18

7 SUMMARY AND CONCLUSIONS. . . . . . . . . . . . . . . . . . 18

REFERENCES. . . . . . . . . . . . . . . . . . . . . . . 20

ACKNOWLEDGMENTS . . . . . . . . . . . . . . . . . . . . . . 21 
1 Diagram of the Union Carbide Enhanced-Tube Condenser. . . . . . . . . 3

2 Union Carbide Condenser Tube. . . . . . . . . . . . . . . . . . 4

3 Union Carbide Enhanced-Tube Condenser . . . . . . . . . . . . . . . . 4

4 OTEC Heat Exchanger Test Facility . . . . . . . . . . . . . . . . 6

5 Sample Data Printout. . . . . . . . . . . . . . . . 9

6 Extended Run Results at 3.2 Million Btu/hr. . . . . . . . . . . . 15

7 Wilson Plot........................... . 17

8 Variation of Water-Side Coefficient with Water Flow Rate. . . . . 18

9 Effect of Heat Duty on $U_{0}$. . . . . . . . . . . . . . . . 18

\section{LIST OF TABLES}

1 Nominal Design Parameters for the Enhanced-Tube Condenser . . . . . . 5

2 Instruments and Measurement Accuracy. . . . . . . . . . . . . . 8

3 Values of $\mathrm{U}_{\mathrm{o}}$ as a Function of Water Flow Rate . . . . . . . . . . . 16

4 Dependence of $h_{i}$ on Water flow Rate . . . . . . . . . . . . . . . . 17

5 Water-Side Pressure Drop as a Function of Flow Rate . . . . . . . . . 19 
Inside surface area of heat exchanger tubes, $\mathrm{ft}^{2}$

Log-mean area of heat exchanger tubes, $\mathrm{ft}^{2}$

Outside surface area of heat exchanger tubes, $\mathrm{ft}^{2}$

Heat capacity of water in condenser, Btu/lb $\bullet^{\circ} \mathrm{F}$

Heat capacity of water in chiller, Btu/ $1 \mathrm{~b} \cdot{ }^{\circ} \mathrm{F}$

Heat of condensation of ammonia in condenser, Btu/lb

Fouling coefficient for inside of tubes, Btu/hr$\cdot \mathrm{ft}^{2}{ }^{\circ} \mathrm{F}$

Fouling coefficient for outside of tubes, Btu/hr$\cdot \mathrm{ft}^{2} \cdot{ }^{\circ} \mathrm{F}$

Heat transfer coefficient for inside surface (water), Btu/hr$\cdot \mathrm{ft}^{2} \cdot{ }^{\circ} \mathrm{F}$

Heat transfer coefficient for inside surface (water) calculated

from the Noranda correlation (Eq. 8), Btu/hr $\cdot \mathrm{ft}^{2} \bullet^{\circ} \mathrm{F}$

Heat transfer coefficient for outside surface (ammonia), Btu/hr$\cdot \mathrm{ft}^{2} \cdot{ }^{\circ} \mathrm{F}$

Conductivity of tube wall material, Btu/hr$\cdot \mathrm{ft} \cdot{ }^{\circ} \mathrm{F}$

Mass flow rate of water through condenser, $1 \mathrm{~b} / \mathrm{min}$

Mass flow rate of water through chiller, $1 \mathrm{~b} / \mathrm{min}$

Mass flow rate of ammonia around loop, $1 \mathrm{~b} / \mathrm{min}$

Prandt 1 number

Water-side pressure drop through condenser, psi

Pressure increase across cold water pump, psi

Rate of heat transferred to cold water in condenser calculated from water temperature change, $\mathrm{Btu} / \mathrm{hr}$

Rate of heat transferred to cold water in condenser calculated from cold-water loop energy balance, Btu/hr

Rate of heat transferred from ammonia stream during passage through the condenser, Btu/hr

Reynolds number

Inside radius of heat exchanger tubes, $\mathrm{ft}$

Outside radius of heat exchanger tubes, $\mathrm{ft}$

Wall thickness $\left(r_{0}-r_{i}\right)$, ft

Temperature of cold water entering condenser, ${ }^{\circ} \mathrm{F}$

Temperature of cold water leaving condenser, ${ }^{\circ} \mathrm{F}$

Saturation temperature of ammonia in condenser, ${ }^{\circ} \mathrm{F}$

Water-side temperature increase through condenser $\left(\mathrm{T}_{\mathrm{co}}-\mathrm{T}_{\mathrm{C} i}\right),{ }^{\circ} \mathrm{F}$

Water-side temperature decrease through chiller, ${ }^{\circ} \mathrm{F}$
$\Delta \mathrm{T}_{1 \mathrm{mc}}$ Log-mean temperature difference in condenser, ${ }^{\circ} \mathrm{F}$

$\mathrm{U}_{0} \quad$ Overall heat transfer coefficient based on outside tube surface area, $\mathrm{Btu} / \mathrm{hr} \cdot \mathrm{ft}^{2 \cdot{ }^{\circ} \mathrm{F}}$

w Cold water flow rate through condenser, gpm

$v \quad$ Kinematic viscosity of water, $\mathrm{ft}^{2} / \mathrm{hr}$ 
NOMENCLATURE 
OTEC PERFORMANCE TESTS OF THE

UNION CARBIDE ENHANCED-TUBE CONDENSER

by

David T. Yung, David L. Hillis, James J. Lorenz, and Norman F. Sather

\author{
ABSTRACT
}

\begin{abstract}
Results of performance tests conducted on a Union Carbide enhanced-tube condenser with wire wrapping on the ammonia side and internal axial fins on the water side are reported. This unit performed satisfactorily and was free of operational difficulties. At design operating conditions (a heat duty of $3.2 \mathrm{million} B t u / h r$, an inlet water temperature of $40^{\circ} \mathrm{F}$, and a water flow rate of $3200 \mathrm{gpm}$ ) the steady-state value of the overall heat transfer coefficient was found to be $818 \mathrm{Btu} /$ $\mathrm{hr} \cdot \mathrm{ft} 2{ }^{\circ} \mathrm{F}$, and the ammonia-side and water-side heat transfer coefficients were 5180 and $1130 \mathrm{Btu} / \mathrm{hr} \cdot \mathrm{ft} 2{ }^{\circ} \mathrm{F}$, respectively. The water-side pressure drop was $1.8 \mathrm{psi}$. Varying the heat duty from $2.4 \mathrm{mill}$ ion to $4.0 \mathrm{mill}$ ion $\mathrm{Btu} / \mathrm{hr}$ had a negligible effect on thermal performance. The value obtained for the ammonia-side heat transfer coefficient at nominal conditions is about two times that predicted by the Nusselt expression for condensation on a smooth tube. The water-side coefficient is within $3 \%$ of the value predicted by the Noranda correlation for finned tubes.
\end{abstract}

\title{
1 INTRODUCTION
}

Energy stored in the warm surface waters of the tropical oceans can be converted to electrical energy in a suitably designed power plant. Although Ocean Thermal Energy Conversion (OTEC) plants can utilize the warm ocean water directly as the working fluid, the primary emphasis in the current federal development program is on closed-cycle plants that use ammonia or some other refrigerant in a Rankine power cycle. In such a plant the warm water is pumped through a heat exchanger where thermal energy of the water is transferred to the ammonia, causing it to vaporize. The vaporized ammonia, under pressure, flows from the exchanger through a turbine-generator that converts the pressure energy into electrical energy. The vapor then flows to a second heat exchanger where the ammonia is condensed at low pressure. Here the heat of condensation is transferred to a cold water stream that is pumped up to the condenser from the ocean depths. Finally, the liquid ammonia is pumped back to the evaporator to complete the cycle.

Since the temperature difference between the warm and cold ocean water is at most $35-40^{\circ} \mathrm{F}$, the net energy conversion efficiency of the plant is 1 ow $(\approx 3 \%)$ and the amount of thermal energy that can be obtained from a pound of water is small (corresponding to $2-4^{\circ} \mathrm{F}$ sensible heat). Consequently, the heat exchangers must handle very large heat duties and water flows, on the order of $100 \mathrm{million} B t \mathrm{hr}$ and 100 thousand gpm per megawatt 
of generating capacity. This means that the heat exchangers will be much larger and more costly than those used in conventional coal and nuclear power plants.

However, improvements in the performance of the evaporator and condenser can significantly reduce both capital and operating costs. The performance of the exchangers is characterized by two quantities, the overall heat transfer coefficient and the water-side and ammonia-side pressure drops. The latter are important because the parasitic power required for pumping is proportional to them. Clearly, cost trade-offs between pumping power and heat-transfer performance are possible. For example, increasing the water velocity through the exchanger will improve the heat transfer coefficient and thereby reduce the amortized equipment cost, but at the expense of a greater pumping power cost. Water-side and ammonia-side heat transfer enhancement techniques offer similar trade-off possibilities and, hence, opportunities for maximizing the overall cost-effectiveness of the heat exchangers. The most cost-effective design would take into account costs of biofouling control, pumping, and the amortized cost of materials and fabrication.

The purpose of this report is to present and discuss the results of performance tests on an enhanced-tube condenser designed by Union Carbide Corporation. The tests were run at the OTEC heat exchanger test facility at Argonne. This condenser is one of a series of five high-performance shelland-tube heat exchangers that have been tested. The other exchangers tested to date are the Union Carbide flooded-bundle evaporator, the Carnegie-Mellon University ( $C-M U)$ vertical fluted-tube condenser, the Union Carbide sprayedbundle evaporator, and the C-MU vertical fluted-tube evaporator. Test results on the first of these have been published, 1 and reports on the others are forthcoming. In addition, the results of performance tests on several shellless types of heat exchangers will be issued later this year. All of the heat exchangers involved are sized to handle $3.2 \mathrm{million} \mathrm{Btu} / \mathrm{hr}$, corresponding to 1/40 MWe capacity. Consequently, through these tests it should be possible to determine whether the performance anticipated on the basis of single-tube experiments can be achieved in large tube-bundle configurations. Such information is necessary before ful1-size commercial OTEC plants can be designed.

\section{ENHANCED-TUBE CONDENSER}

The enhanced-tube condenser was supplied by the Linde Division of the Union Carbide Corporation as part of the DOE OTEC heat exchanger development program. The condenser, a horizontal shell-and-tube heat exchanger, has 1.5-in.-0.D. aluminum (3003) tubes with external wire wrapping and internal axial fins. Details of the Union Carbide condenser are shown in Figs. 1 and 2 , and an illustration is provided in Fig. 3. The external wire wrapping, which is in contact with ammonia, promotes thin-film condensation; the internal axial $f$ in arrangement, which is in contact with water, promotes turbulent convection. The water side is single pass with the cold water entering one end of the condenser and passing horizontally to the other end. Ammonia vapor enters from the top and the condensate leaves from the bottom. Table 1 gives the nominal design/operating parameters for this condenser. 


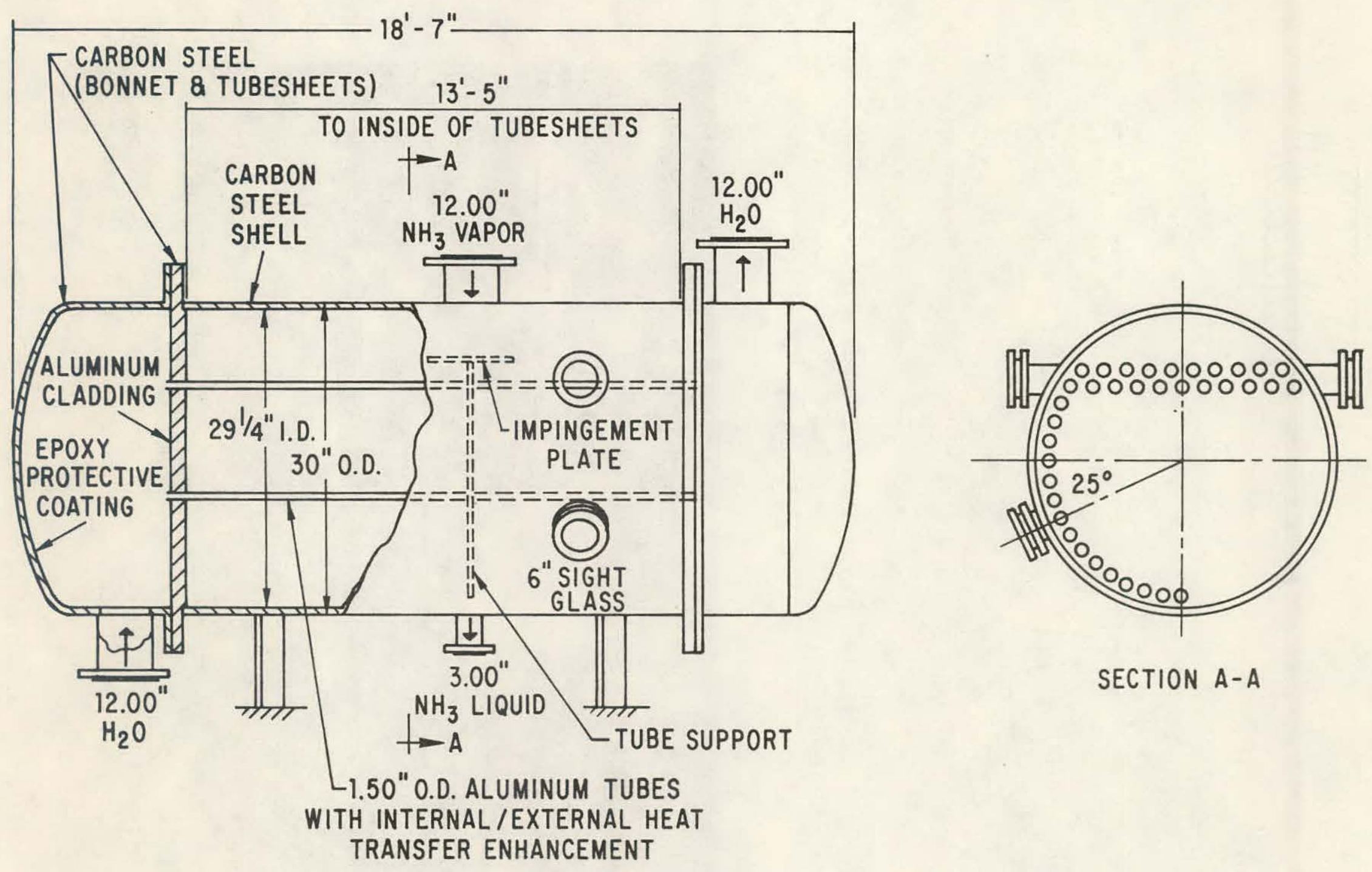

Fig. 1. Diagram of the Union Carbide Enhanced-Tube Condenser 

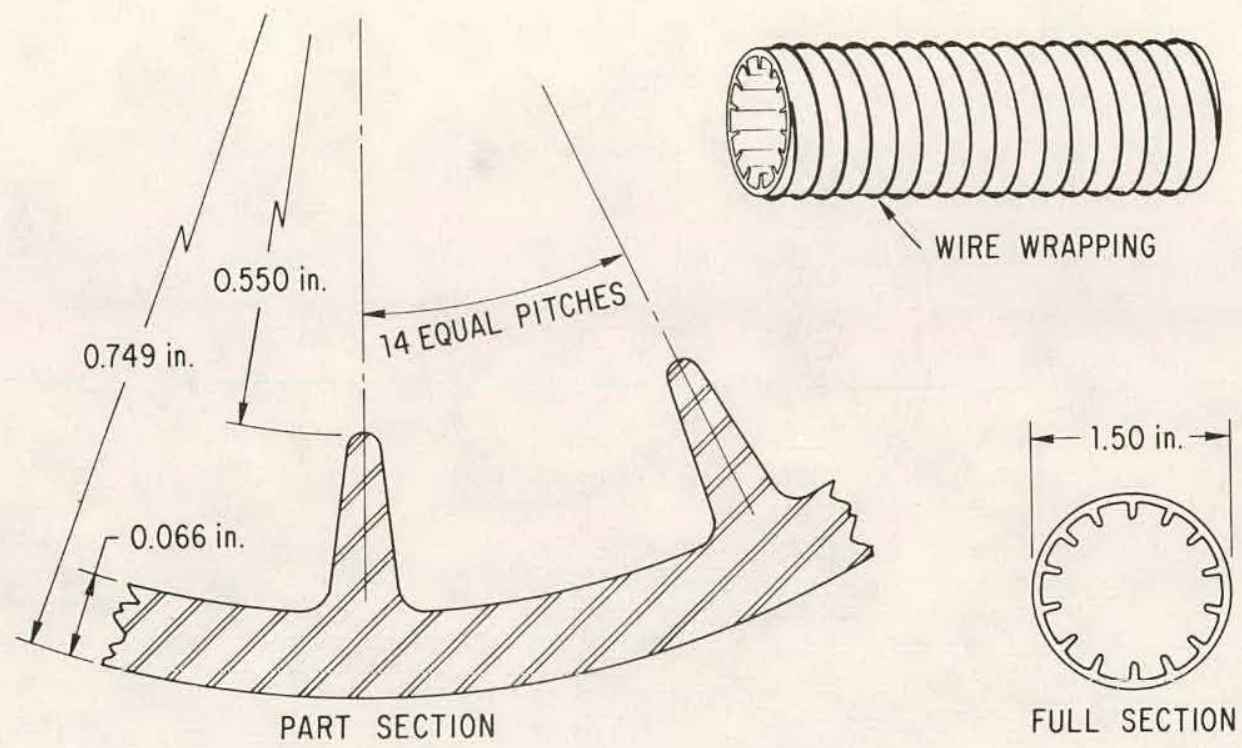

FULL SECTION

Fig. 2. Union Carbide Condenser Tube

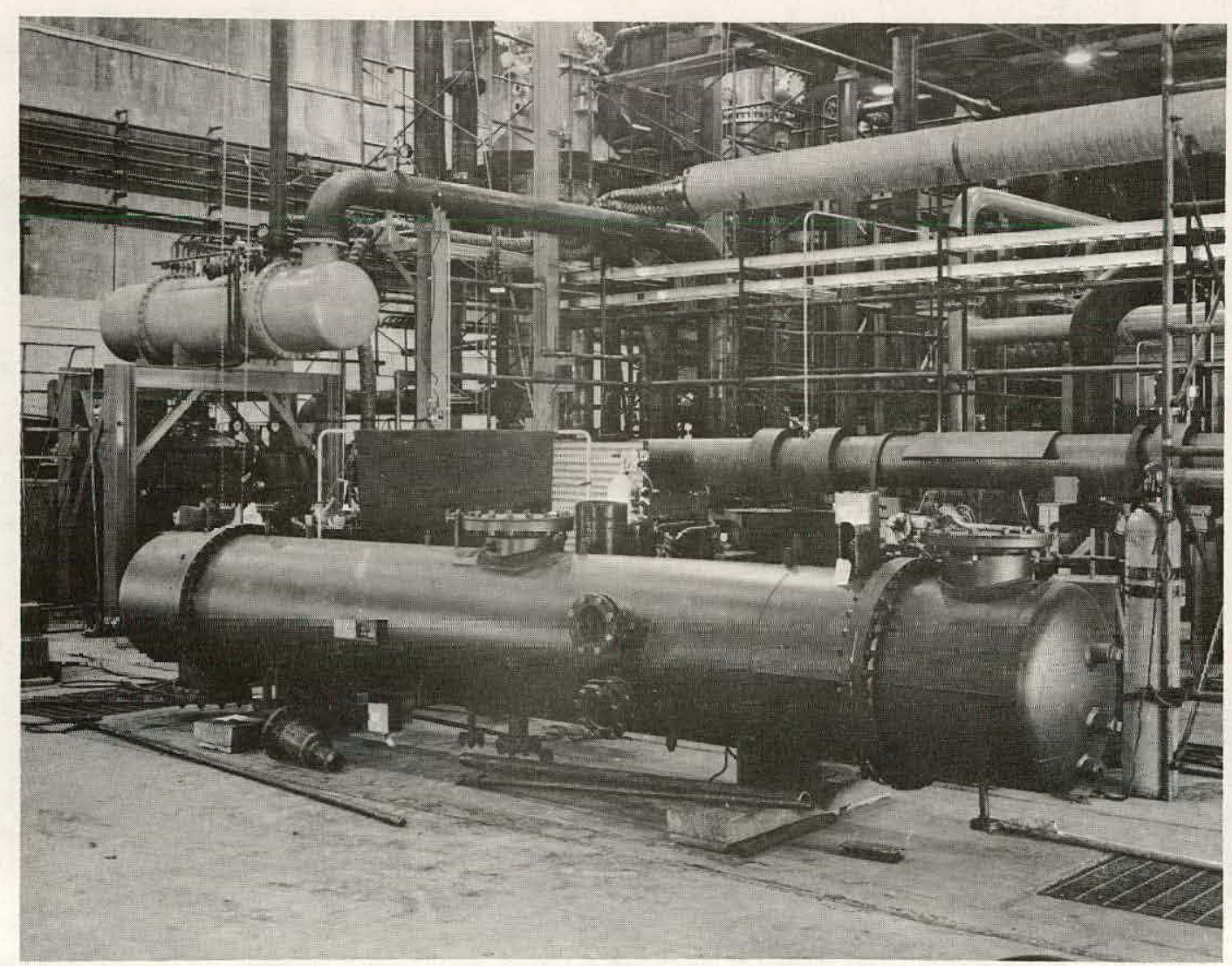

Fig. 3. Union Carbide Enhanced-Tube Condenser 
Table 1. Nominal Design Parameters for the Enhanced-Tube Condenser

\begin{tabular}{lc}
\hline \multicolumn{1}{c}{ Parameter } & Value \\
\hline Heat duty & $3.2 \mathrm{million} \mathrm{Btu/hr}$ \\
Ammonia condensing temperature & $48^{\circ} \mathrm{F}$ \\
Water inlet temperature & $40^{\circ} \mathrm{F}$ \\
Water outlet temperature & $42^{\circ} \mathrm{F}$ \\
Number of tubes & 147 \\
Externally enhanced tube length & $154.5 \mathrm{in}$. \\
Tube outside diameter (excluding wrapped wire) & $1.50 \mathrm{in}$. \\
Tube inside diameter & $1.37 \mathrm{in}$. \\
Effective outside heat transfer area & $743 \mathrm{ft}{ }^{2}$ \\
Mean water velocity in tubes & $4.7 \mathrm{ft}_{\mathrm{sec}}$ \\
Overall water-side pressure drop & $2.0 \mathrm{psid}$ \\
Shell inside diameter & $29.25 \mathrm{in}$. \\
Shell-side design pressure & $215 \mathrm{psig}^{\mathrm{b}}$ \\
Tube-side design pressure & $100 \mathrm{psig}^{\circ}$ \\
"Clean" overall heat transfer coefficientc & $780 \mathrm{Btu} / \mathrm{hr}^{\circ} \mathrm{ft}^{2}{ }^{\circ} \mathrm{Fb}^{\mathrm{b}}$ \\
\hline
\end{tabular}

Source: Czikk, A.M., et al., Fluid Dynamic and Heat Transfer Studies of OTEC Heat Exchangers, Proc. Fifth Ocean Thermal Energy Conversion Conf., Vol. 3, Miami Beach, Fla. (Feb. 20-22, 1978).

abased on outside diameter without wrapped wire and on actual enhanced tube length of $154.5 \mathrm{in.}$; the total tube length between the tube sheets is $6.4 \mathrm{in}$. longer.

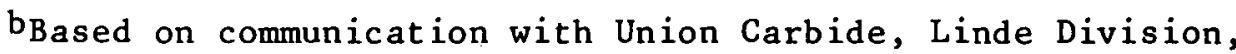
Tonawanda, New York.

cBased on outside. tube surface area. Assumes no tube-side or shel1-side fouling.

\section{HEAT EXCHANGER TEST FACILITY}

\subsection{PIPING LAYOUT}

A piping schematic of the OTEC heat exchanger test facility at Argonne is shown in Fig. 4. The facility consists of a warm water loop, a test evaporator, an ammonia loop, a test condenser, and a cold water loop.

The nominal heat duty of the warm water loop is $3.2 \mathrm{million} B \mathrm{Btu} / \mathrm{hr}$; however, the heater and steam supply line are sized to handle up to 6 million $\mathrm{Btu} / \mathrm{hr}$. The heater can be set for a constant heat duty over the range of 0.5 million-6 million Btu/hr. The warm water flow rate is a nominal $3200 \mathrm{gpm}$, but the pipe and pump are sized for flows up to $8000 \mathrm{gpm}$. This large range of flows improves the accuracy of calculation of the individual water-side and ammonia-side heat transfer coefficients. An important feature of the flow 

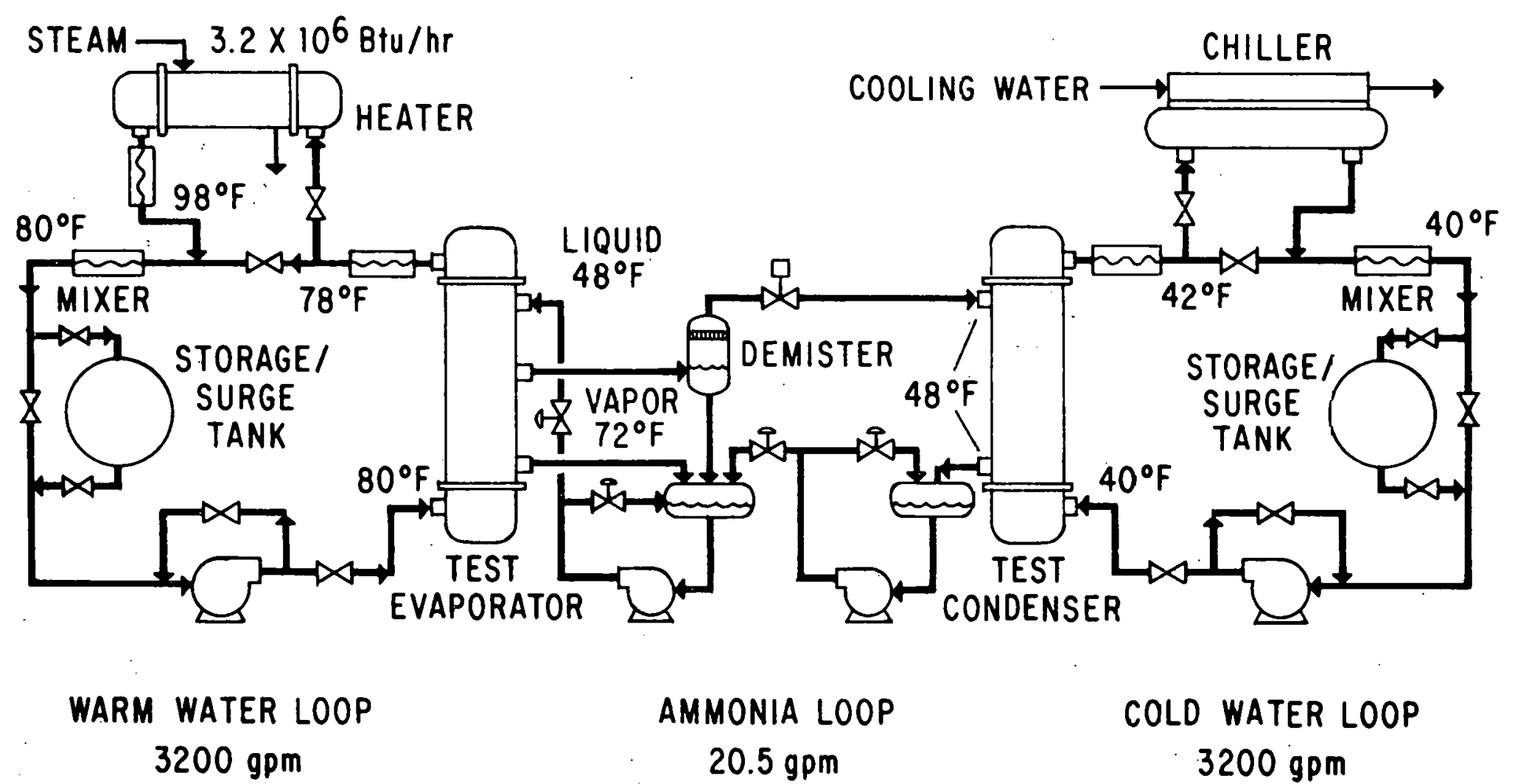
AMMONIA LOOP
$20.5 \mathrm{gpm}$
COLD WATER LOOP $3200 \mathrm{gpm}$

Fig. 4. OTEC Heat Exchanger Test Facility 
loop is a bypass around the warm water heater. Typically, about $10 \%$ of the water flows through the heater and $90 \%$ flows through the bypass line. The temperature of the water passing through the heater is raised by about $20^{\circ} \mathrm{F}$; when the heated water is mixed with the water from the bypass line, the desired water temperature is achieved. This arrangement greatly improves the accuracy of measurement of the heat input from the steam heater. Static mixers are used to eliminate radial temperature variations at locations where measurements of bulk mean temperatures are needed.

The ammonia loop is provided with a demister that removes entrained liquid droplets from the vapor stream. The demister contains a 6-in.-thick pad woven from polypropylene filaments. The ammonia droplets are caught on the pad and returned to the evaporator as a liquid stream from the bottom of the demister vessel. The manufacturer's rating indicates that all but submicron-sized particles are caught at the vapor velocities of the tests. The ammonia loop also contains an expansion valve for adjusting the pressure of the vapor supplied to the test condenser.

The cold water loop contains a chiller capable of removing up to 6.4 million $B t u / h r$ from the recirculating cold water flow. Condenser inlet water temperatures as $10 \mathrm{o}$ as $40^{\circ} \mathrm{F}$ are possible over most of the range of heat duties. However, at duties above $5 \mathrm{million} \mathrm{Btu} / \mathrm{hr}$, a $40^{\circ} \mathrm{F}$ cold water temperature cannot be attained because the required refrigerant temperature is below the capability of the chiller. The nominal cold water flow rate is $3200 \mathrm{gpm}$, but the pump and pipe are sized to handle as much as $8000 \mathrm{gpm}$ if necessary. The chiller is rated at $4000 \mathrm{gpm}$ maximum; the bypass around the chiller can be used to obtain the higher flows needed for determining the film heat transfer coefficients. Static mixers are also used in the cold water loop to facilitate measurement of bulk mean temperatures.

\subsection{INSTRUMENTATION}

Pressures, temperatures, and flow rates are measured in each of the three test facility loops. The instruments used were chosen on the basis of measurement accuracy and compatibility with the computer data handing system. The original accuracy goals for measurements characterizing overall performance of the heat exchangers were $\pm 3 \%$ for the overali heat transfer coefficient and $\pm 5 \%$ for the water-side pressure drop. In all instances these goals were met or surpassed during testing. Table 2 lists the more important instruments used and the accuracy of measurement obtained routinely during test operations.

\subsection{DATA HANDLING SYSTEM}

The test facility has a computer-based data system that can, on command, read the sources of data, apply calibration and correction factors to these data, compute heat balances and overall heat transfer coefficients, and produce hard-copy records of all measured and calculated quantities. Figure 5 shows a typical hard-copy output of the data calculated for a particular test run. Most of the entries in Fig. 5 are self-explanatory; those that are not will be discussed in Sec. 5 . 
Table 2. Instruments and Measurement Accuracy

\begin{tabular}{|c|c|c|}
\hline Quantity measured & Instrument & $\begin{array}{l}\text { Accuracy of } \\
\text { measurement }\end{array}$ \\
\hline \multicolumn{3}{|l|}{ Temperature of: } \\
\hline $\begin{array}{l}\text { Water into and out of condenser } \\
\text { Ammonia vapor after expansion valve }\end{array}$ & $\begin{array}{l}\text { Quartz crystal } \\
\text { thermometer }\end{array}$ & $\pm 0.010^{\circ} \mathrm{F}$ \\
\hline Water into and out of chiller & $\begin{array}{l}\text { Copper-constantan } \\
\text { thermocouple }\end{array}$ & $\pm 0.1^{\circ} \mathrm{F}$ \\
\hline \multicolumn{3}{|l|}{ Pressure of: } \\
\hline $\begin{array}{l}\text { Ammonia vapor in condenser and after } \\
\text { expansion valve }\end{array}$ & $\begin{array}{l}\text { Quartz crystal } \\
\text { transducer }\end{array}$ & \pm 0.005 psia \\
\hline \multicolumn{3}{|l|}{ Pressure difference of: } \\
\hline $\begin{array}{l}\text { Water into and out of condenser } \\
\text { Water into and out of cold water } \\
\text { pump }\end{array}$ & $\begin{array}{l}\text { Strain gauge } \\
\text { transducer }\end{array}$ & $\begin{array}{l} \pm 0.5 \% \\
\text { of reading }\end{array}$ \\
\hline \multicolumn{3}{|l|}{ Flow rate of: } \\
\hline $\begin{array}{l}\text { Water through condenser } \\
\text { Water through chiller bypass }\end{array}$ & Turbine meter & $\begin{array}{l} \pm 0.15 \% \\
\text { of reading }\end{array}$ \\
\hline Liquid ammonia feed to evaporator & Turbine meter & $\begin{array}{l} \pm 0.5 \% \\
\text { of reading }\end{array}$ \\
\hline
\end{tabular}

\section{OPERATING PROCEDURE}

The Union Carbide enhanced-tube condenser was installed in the test loop in the condition in which it had been received, without cleaning, since the heat transfer surfaces had been maintained in a protected, clean condition during shipment. Cleanliness was also maintained during installation.

As for the test facility itself, this had been cleaned prior to the initial start-up, and the process was not repeated. During the initial cleaning, all piping, valves, and vessels of the ammonia system (excluding the test heat exchangers) were cleaned with hot caustic to remove grease. Acid washing (pickling) was then performed to remove rust, mill scale, and particles of iron left from the welding performed during fabrication. The surfaces were then passivated, flushed with water, and put under a nitrogen blanket. Initially, the ammonia system had been evacuated to remove noncondensables and water from the ammonia sides of the heat exchangers and from the ammonia piping. When the Union Carbide condenser was added to the loop, it was checked for leaks, evacuated, back-filled with ammonia, and isolated from the rest of the system under a positive ammonia pressure.

This condenser was not used during the tests of the Union Carbide flooded-bundle evaporator nor during the initial tests of the Union Carbide sprayed-bundle evaporator. Midway through tests of the sprayed-bundle evap- 
$11 / 28 / 1978$

$11: 30$

LINDE CONDENSER

RUN * 53

WATER TEMP CHILLER IN= 43.200DEG $F$ WATER TEMP CHILLER OUT: $40.767 D E G ~ F$

WATER TEMP COND IN= 41.407DEG $F$ WATER TEMP COND OUT= $43.354 D E G: F$

NH3 TEMP COND IN $=47.528 D E G ~ F$ NH3 TEMP COND OUT= 47.467 DEG $F$

QUARTZ P AFTER R VALVE 84.986PSIA

QUARTZ T AFTER $R$ VALVE 54.853DEG $F$

CHILLER WATER FLOW= 31.71 .384 GPM

COND WATER FLOW= $3180.375 G P M$

NH3 LOOP FLOW- $\quad 8.236 \mathrm{GPM}$

NH3 DEMISTER FLOW= B.DDEGPM

WATER TEMP CHANGE IN CHILLER $=-2.433 D E G ~ F$

WATER TEMP CHANGE IN COND.CALCD.MEASD IN DEG $F \quad 1.948 \quad 1.953$

LOGMEAN TEMP DIFF $=$ 5. D99DEG $F$

HEAT INPUT TO CHILLER $=0.3888 E$ PBTU/HR

NET HEAT IN TO COND $=0.3427 E$ TBTU/HR

HEAT IN DUE TO PUMP $=0.4601 E$ GBTU/HR

HEAT INTO COND BASED ON H2O DELTA T= 0.3104E 7BTU/HR

HEAT INTO COND BASED ON NH3 COND RATE = 0.1369E TBTU/HR

HT XCHGR AREA $=743.80 B F T 2$

HT XFER COEF BASED ON H20 DELTA T: $0.8193 E$ 3BTUMRAFT2 DEGF

HT XFER COEF BASED ON HT BALANCE - $0.9845 E$ 3BTU HR FT2 $/ D E G F$

WATER PRESSURE CHANGE IN COND $=$ 2:147PSI

COLD WATER PUMP DELTA $P=96.821 \mathrm{PSI}$

H3 COND PRES = 84.957PSIA

NH3 LOOP MASS FLOW RATE $=\quad$ 43. OPQLBS MIN

Fig. 5. Sample Data Printout 
orator, it was decided to start using the Union Carbide condenser in anticipation of full-scale testing scheduled later. (Until that time, the C-MU condenser had been used; testing on that unit had been completed.) When the Union Carbide condenser was first valved into the main ammonia loop, several leaks developed in the interconnecting piping when system pressure was raised over 80 psi. These were located and corrected by tightening bolted connections.

The cold water loop had also been cleaned and passivated by the same procedure used for the ammonia system. The loop was then filled with potable water that had first been through two water-softening treatments. A corrosion and fouling inhibitor (Nalco 8330) was added to the water in the approximate ratio of 3 oz per gal.

The first step in the start-up procedure was to fill the condenser and evaporator receivers (sumps) one-half to three-quarters full of ammonia. Since the sprayed-bundle evaporator was used in this test, its ammonia head was also filled. The two ammonia pumps were then started, recirculating ammonia through the receivers in a bypass mode of operation. The cold water pump, the chiller, and the warm water pump were turned on. Water flows were initially adjusted to $3200 \mathrm{gpm}$, and the cold water temperature was set at about $41.5^{\circ} \mathrm{F}$. (The nominal temperature of $40^{\circ} \mathrm{F}$ is difficult to maintain on a steady-state basis.) Next, the ammonia flow to the evaporator was started and the evaporator pressure adjusted to about 134 psia. Finally, the steam heater was turned on and adjusted to keep the warm water temperature at $80^{\circ} \mathrm{F}$.

After start-up, it generally takes two to four hours to reach equilibrium before data-taking can commence. Data are recorded for two hours or more before changing operating parameters. Generally, a set of hard-copy data is taken every 10 to 20 minutes, with intermediate points often read and plotted but not printed. The data reported here were obtained during a continuous run of about 100 hours starting Monday morning, November 27, and ending Friday afternoon, December 1, 1978. (Preliminary data had been recorded on November 7 and 8 incidental to testing of the sprayed-bundle evaporator.)

The test program consisted essentially of three Wilson-plot runs at 2.4 million, $3.2 \mathrm{million}$, and $4.0 \mathrm{million} B t u / \mathrm{hr}$ and at cold water flow rates of $1500,2400,3200,4000$, and $5000 \mathrm{gpm}$. It soon became apparent that there was much more variability in the calculated $U_{0}$ values than was typical in the case of heat exchangers previously tested. The problem appeared to lie in the cycling of the expansion valve, which was operating in an automatic mode. Condenser pressure was varying by about 1.5 psi over a regular cycle of some 40 seconds. Since condensing temperature (and hence $\Delta \mathrm{T}_{1 \mathrm{mc}}$ ) was calculated from the pressure (instead of measured directly), the reported $U_{0}$ values were affected by the timing of the start of data-taking. A little experimentation clearly confirmed this effect. When the expansion valve was switched to manual control, the pressure swings were reduced by a factor of three, and the data smoothed out accordingly. The testing was completed with the expansion valve under manual control.

At the end of the test period, the system was shut down in approximately the reverse order in which it was started up, and the ammonia was transferred to storage tanks located outside the building. For reasons of safety, ammonia was not left in the system while it was unattended. 


\section{METHODS OF CALCULATION}

\subsection{EQUATIONS FOR THE OVERALL HEAT TRANSFER COEFFICIENT}

It is evident from the foregoing discussion of the measurements made during testing that there are three independent ways of determining the heat duty of the condenser. These are:

1. The rate at which heat is taken up by the cold water as it passes through the condenser. This can be expressed as follows:*

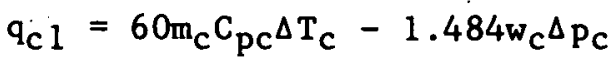

where the first term is the sensible heat gained by the water as it flows through the condenser, and the second corrects for the frictional heat added. As might be expected, the frictional heat addition is quite small, amounting to less than $0: 5 \%$ of $\mathrm{q}_{\mathrm{cl}}$ for all runs with the condenser.

2. The rate at which heat is removed from the cold water as it flows around the loop from the condenser discharge nozzle back to the condenser inlet. This includes the net effect of the heat removed in the chiller and added in the pump work. The cold water piping system is heavily insulated, so convective heat losses are negligible. Thus:

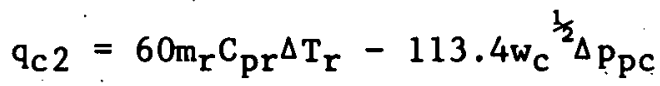

The second term on the right side of Eq. 2 represents the rate of heat addition to the water by the pump. "This term was obtained by making an empirical curve fit. to the manufacturer's efficiency data for this pump for flows between 2400 and $4000 \mathrm{gpm}$. This was checked by direct determination of the heat addition from measurements of the water temperature change through the pump at different flow rates.

3. The rate at which heat is removed from the ammonia as it passes through the condenser:

$$
\mathrm{q}_{\mathrm{c}}^{\prime}=60 \mathrm{~m} \ell \Delta \mathrm{H}_{\mathrm{c}}^{\prime}
$$

During steady-state operation these three values of the condenser heat

duty $\left(q_{c 1}, q_{c 2}\right.$, and $\left.q_{c}^{\prime}\right)$ must be equal; consequently, the accuracy of the measurements can be checked by comparing the values obtained from the experimental data. However, it must be emphasized that the three methods are not equally accurate. Therefore, it cannot be assumed that the difference between the results obtained by any two methods represents the error in either method.

* See list of nomenclature for explanation of symbols. 
Once a value of the condenser heat duty, $q_{c}$, is obtained, the overall heat transfer coefficient, $U_{0}$, is calculated from the conventional definition:

$$
\mathrm{u}_{\mathrm{o}}=\frac{\mathrm{q}_{\mathrm{c}}}{\mathrm{A}_{\mathrm{o}} \Delta \mathrm{T}_{1 \mathrm{mc}}}
$$

where:

$$
\begin{aligned}
\mathrm{A}_{\mathrm{O}}= & \text { the outside surface area of the tubes (without } \\
& \text { wrapped wire), and } \\
\Delta \mathrm{T}_{1 \mathrm{mc}}= & \text { the log-mean temperature difference between the } \\
& \text { water and ammonia streams. }
\end{aligned}
$$

The quantity $\Delta T_{1 m c}$ can be expressed in equation form as follows:

$$
\Delta \mathrm{T}_{1 \mathrm{mc}}=\frac{\Delta \mathrm{T}_{\mathrm{c}}}{\ln \left[\frac{\mathrm{T}_{\mathrm{c}}^{\prime}-\mathrm{T}_{\mathrm{ci}}}{\mathrm{T}_{\mathrm{c}}^{\prime}-\mathrm{T}_{\mathrm{co}}}\right]}
$$

Here, $T_{c}^{\prime}$ is the saturation temperature of the ammonia vapor fed to the condenser; for these tests this temperature was calculated from the measured inlet pressure rather than'measured directly, because more accurate values could be obtained in that way.

\subsection{ERROR ANALYSIS}

Before the test data on the enhanced-tube condenser and the resulting heat transfer coefficients calculated from these equations are presented, a brief discussion of the magnitude of the expected uncertainties in $q_{c}$ and $U_{0}$ that result from inaccuracies in the directly measured quantities is perhaps in order. We can determine these uncertainties by analyzing the propagation of the potential measurement errors (discussed in Sec. 3.2) in calculations with Eqs. 1 to 5 above.

The first method of calculating the heat duty (Eq. 1) involves the $\Delta T_{c}$ measurement (with a measurement accuracy of $\pm 0.3 \%$ ) and the flow rate measurement ( $\pm 0.15 \%$ accuracy); the expected accuracy in $q_{c l}$ is therefore $\pm 0.4 \%$ (note that the error contribution of the frictional term is negligible). This is in agreement with the observed scatter in the values of $q_{c l}$ calculated from successive measurements during steady operation at fixed run conditions; the data generally fell well within a band that was $1 \%$ wide.

The uncertainty in $U_{o}$ is determined by examining the following equation, which results from combining Eqs. 1, 4, and 5 and neglecting the frictional heat addition:

$$
\mathrm{U}_{\mathrm{o}} \simeq \frac{60 \mathrm{~m}_{\mathrm{c}} \mathrm{C}_{\mathrm{pc}}}{\mathrm{A}_{\mathrm{o}}} \ln \left[\frac{\mathrm{T}_{\mathrm{c}}^{\prime}-\mathrm{T}_{\mathrm{ci}}}{\mathrm{T}_{\mathrm{c}}^{\prime}-\mathrm{T}_{\mathrm{co}}}\right]
$$


The uncertainty in $U_{O}$ is due in part to inaccuracies in measurements of $\mathrm{T}_{\mathrm{ci}}$ and $\mathrm{T}_{\mathrm{co}}$ obtained with quartz crystal thermometers. These inaccuracies arise from the inherent precision limits of the thermometers and from small errors introduced during calibration. The standard calibration procedure is to place both measuring probes in a slush of ice made from distilled water. The readings are allowed to stabilize, and each probe is adjusted to read $32^{\circ} \mathrm{F}$. Further improvement in the accuracy of the measurement of $\mathrm{T}_{c o}-\mathrm{T}_{\mathrm{ci}}$ $c$ an be made by adjusting the instrument at the operating temperature of $42^{\circ} \mathrm{F}$. After the standard calibration was completed, simultaneous readings of the cold water temperature at the same point in the loop were made with the two probes. Both were then adjusted to indicate the average of the original readings, and $\Delta T$ was adjusted to read zero. Values for $T_{c i}, T_{c o}$, and $\Delta T_{c}$ are given in Fig. 5; "water temp cond in" is $\mathrm{T}_{c i}$, "water temp cond out" is $\mathrm{T}_{c o}$, and "water temp change in cond" is $\Delta T_{c}$. It can be noted that $T_{c o}-T_{c i} d i f-$ fers from $\Delta \mathrm{T}_{c}$ by $0.005^{\circ} \mathrm{F}$. This is typical of the discrepancy in the two readings of the difference between $\mathrm{T}_{\mathrm{ci}}$ and $\mathrm{T}_{\mathrm{co}}$. Hence, we will use $\pm 0.010^{\circ} \mathrm{F}$ as the maximum measurement error in readings of $\Delta T_{c}, T_{c i}$, and $T_{c o}$. The error in $T_{c}^{\prime}$ resulting from $a \pm 0.005$ psi uncertainty in the ammonia pressure measurement is $\pm 0.003^{\circ} \mathrm{F}$.

By applying these measurement errors to Eq. 6, the uncertainty in $U_{0}$ can now be calculated. A $0.003^{\circ} \mathrm{F}$ error in $T_{c}^{\prime}$ causes a relatively small $( \pm 0.043 \%)$ error in the natural logarithm factor. However, errors of $0.010^{\circ} \mathrm{F}$ in $\mathrm{T}_{\mathrm{ci}}$ and $\mathrm{T}_{\text {co }}$ cause errors in this factor of $\pm 0.435 \%$ and $\pm 0.580 \%$, respectively, at our operating conditions. Hence, the estimated uncertainty in $U_{0}$ is the combined effect of the flowmeter uncertainty $( \pm 0.15 \%)$ and the three sources of uncertainty because of possible errors in $T_{c i}, T_{c o}$, and $T_{c}^{\prime}$. Since these error components are independent of one another, the total probable error is $\pm\left(0.15^{2}\right.$ $\left.+0.435^{2}+0.580^{2}+0.043^{2}\right)^{\frac{1}{2}}= \pm 0.74 \%$.

The second method of calculating the heat duty $\left(q_{c 2}\right)$ is subject to a different set of errors. The first term in Eq. 2 is the rate at which heat is removed from the cold water in the chiller. The flow through the chiller is measured by a turbine flowmeter to $\pm 0.15 \%$ of the actual flow. The value of $\Delta \mathrm{T}_{\mathrm{r}}$ is measured to $\pm 0.2^{\circ} \mathrm{F}$ in about $2.5^{\circ} \mathrm{F}$, or to $\pm 8 \%$. Thus, the total uncertainty in $q_{c 2}$ from this term is $\pm 8 \%$. The second term in Eq. 2 was derived from pump efficiency data supplied by the pump manufacturer. It contributes an uncertainty to $q_{c 2}$ of $\pm 1.3 \%$. Hence, the total estimated uncertainty in $q_{c 2}$ is about $10 \%$.

The third method for computing the heat duty is based on the rate at which energy is removed from the ammonia as it passes through the condenser. Although measured by. a turbine meter that is accurately calibrated $( \pm 0.5 \%)$, the ammonia flow ( $m_{\ell}$ ) is rather unsteady for the following reason. The flow is controlled by a valve operated by $\Delta p$ cells that indicate the liquid levels in the evaporator and condenser sumps. The valve controller is set up to keep the liquid in the receivers at a constant level so as to ensure a positive supply of liquid ammonia to the pump inlets at all times. Hence, although the instruments hold the liquid in the sumps at an almost constant level, the amsonia flow varies widely between the maximum and minimum. Attempts to improve this did not result in a steady flow. Manual control of the flow valve steadied the flowmeter reading, but not at the correct value, since invariably the liquid levels drifted higher or lower over time. Furthermore, the flowmeter apparently was not functioning properly during tests of the condenser, 
and recorded flow rates were consistently below the calculated average value based on heat duty. For these reasons no quantitative use can be made of the values of $q_{c}^{\prime}$ other than as a rough check on $q_{c l}$ and $q_{c} 2$. No calculations of $\mathrm{U}_{\mathrm{o}}$ based on $\mathrm{q}_{\mathrm{c}}^{\prime}$ were made.

of the three possible methods described above, the first is clearly the most accurate and is used exclusively in calculations reported here.

\section{TEST RESULTS 2}

Heat transfer performance of the Union Carbide condenser was measured during November and December 1978, the primary test data being taken during a 32-hour run from November 27 to November 28. The test run was conducted at three different heat duties with the nominal $3.2 \mathrm{milli}$ ion Btu/hr first, 2.4 $\mathrm{milli}$ on $\mathrm{Btu} / \mathrm{hr}$ second, and $4.0 \mathrm{million} B t u / \mathrm{hr}$ last. For each heat duty, the overall heat transfer coefficient was obtained for the nominal flow rate of $3200 \mathrm{gpm}$ and for various other flow rates from 1500 to $5000 \mathrm{gpm}$. The measurements at different flow rates provided the information for determining the individual heat transfer coefficients by the Wilson method.

\section{$6.1 \mathrm{U}_{\mathrm{O}}$ AT DESIGN OPERATING CONDITIONS}

At nominal design conditions (a heat duty of $3.2 \mathrm{million} B t u / h r$ and a water flow rate of $3200 \mathrm{gpm}$ ) the overall heat transfer coefficient $\left(U_{0}\right)$ was

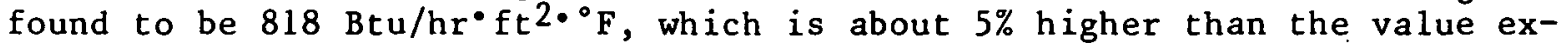
pected by Union Carbide (see Table 1). Test data from the run at a constant heat duty of $3.2 \mathrm{million} B t \mathrm{~h} / \mathrm{hr}$ and at various water flow rates are shown in Fig. 6. It can be seen that the overall heat transfer coefficient for the nominal water flow rate of $3200 \mathrm{gpm}$, obtained on three separate occasions during the test cycle, is repeatable at an average value of $818 \mathrm{Btu} / \mathrm{hr}^{\circ} \mathrm{ft}^{2 .}{ }^{\circ} \mathrm{F}$. The scatter of the data in Fig. 6 is relatively large ( $\pm 4 \%)$ compared to the scatter observed in tests with other units $( \pm 1 \%)$. However, much of the scatter shown in the figure is not real, but merely reflects pressure oscillations caused by the cycling of the expansion valve in the automatic mode (see Sec. 4 ). Since the condensing temperature (and hence $\Delta \mathrm{T}_{1 \mathrm{mc}}$ ) is calculated indirectly from the pressure (rather than measured directly), the reported $U_{0}$ values are affected accordingly. Although the pressure oscillates, the condenser saturation temperature remains essentialiy constant at the timeaveraged condenser pressure. Thus, despite these fluctuations in $U_{0}$, the time-averaged value should be very accurate.

It should be noted that immediately prior to these test runs no venting was done to remove the noncondensables. It was found later that purging the noncondensables increased the overall heat transfer coefficient by $3 \%$

(see Sec. 6.4).

\subsection{INDIVIDUAL HEAT TRANSFER COEFFICIENTS}

Individual ammonia-side and water-side heat transfer coefficients can be determined by the standard Wilson procedure. This procedure makes use of 


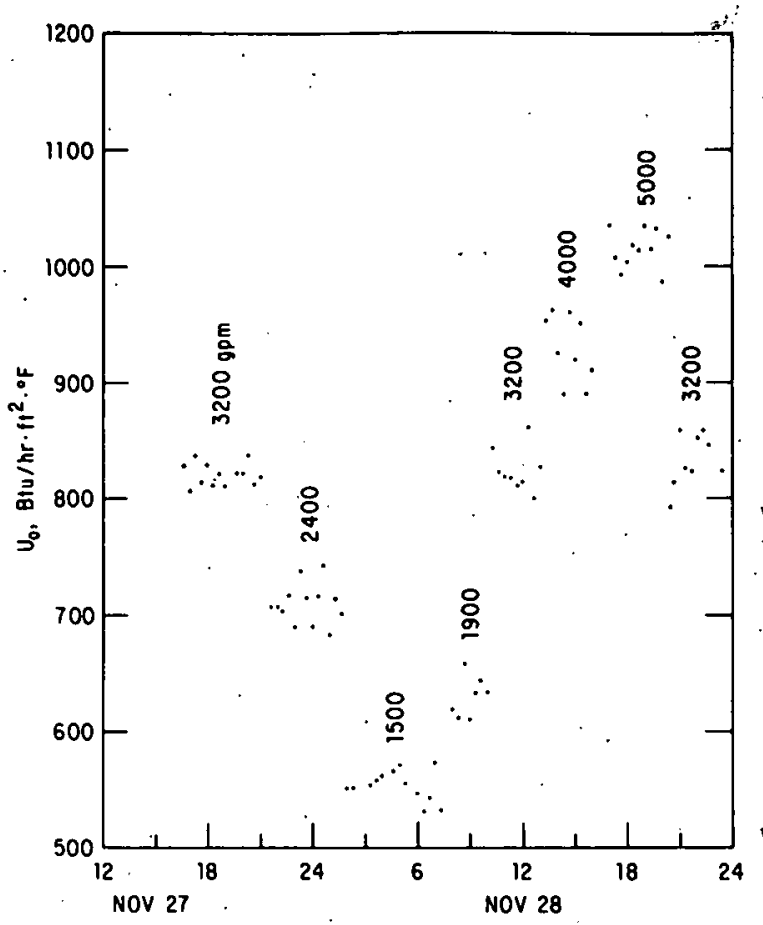

Fig. 6. Extended Run Results at 3.2 Million Btu/hr the relationship between $U_{0}$ and the individual coefficients that expresses the total heat transfer resistance as the sum of its separate components. For circular-tube heat exchangers this relationship is:

$$
\frac{1}{U_{o}}=\frac{A_{o}}{h_{i} A_{i}}+\frac{1}{h_{o}}+\frac{\Delta r A_{o}}{k A_{1 m}}+\frac{A_{o}}{h_{f i} A_{i}}+\frac{1}{h_{f o}}
$$

where $\mathrm{U}_{\mathrm{O}}^{-1}$ is seen to depend 1 inearly on $\mathrm{h}_{\mathrm{i}}{ }^{-1}$. For circular tubes with internal fins of the type used in the Union Carbide condenser, Noranda ${ }^{3}$ has developed the following empirical correlation:

$$
\mathrm{h}_{\mathrm{N}}=0.178 \mathrm{Re}^{0.66} \mathrm{Pr}^{0.33} \mathrm{k} / \mathrm{D}
$$

where $D$ is the inside diameter of the tubes and the Reynolds number is defined as:

$$
\operatorname{Re}=\frac{16.04 w_{c}}{\pi r_{i v}}
$$

Thus, if a sèries of runs are made over a range of water flow rates, $w_{c}$, under conditions where $h_{0}$ is constant, a plot of the values of $U_{0}^{-1}$ versus $w_{c}-0.66$ wili fall on a straight line (assuming, of course, that the physical properties are constant from run to run, as is the case in the present test). Extrapolation of the line to the intercept at $w_{c}-0.66=0$ will yield a value of $\mathrm{U}_{\mathrm{o}}^{-1}$ that is equal to the sum of the last four terms on the right side of.Eq. 7. The value of the ammonia-side coefficient, $h_{0}$, can then be determined by subtracting the values of the tube wall and fouling resistances, if they are known. It should be pointed out that the ammonia-side heat transfer coefficient is a function of local condensate loading, which, of course, varies from tube to tube. Consequently, the $h_{0}$ value in Eq. 7 represents an average value for the bundle. Finally, the values of the water-side coefficient, $h_{i}$, can be obtained for each value of $w_{c}$.

Clearly, the use of this procedure for determining $h_{0}$ and $h_{i}\left(w_{c}\right)$ requires that the data on $U_{o}\left(w_{c}\right)$ be obtained under conditions where $h_{o}$ is constant and the fouling coefficients, $h_{f o}$ and $h_{f i}$, are known. To ensure that $h_{0}$ remained the same during the runs at different water velocities, the condenser heat duty, $q_{c}$, was held constant at the nominal design value of $3.2 \mathrm{mil}$ lion $\mathrm{Btu} / \mathrm{hr}$. As a result, the total condensate flow rate (and hence the average value of $h_{0}$ ) was essentially constant.

It should be noted that although the inlet cold water temperature was held constant, the ammonia-side temperature had to vary slightly from run to run in order to accommodate the different values of $U_{0}$. Consequently, the profiles of the local difference between the ammonia and water temperature along the length of the tubes were not the same for the different water flow. rates. However, the small variations in temperature should not significantly affect the flow 
characteristics or the thermophysical properties of the condensate film, and the $h_{o}$ value can, therefore, still safely be regarded as constant during the runs for the Wilson determination of $h_{0}$.

The situation with respect to the fouling resistances is perhaps somewhat less evident, particularly in the case of the water-side fouling coefficient, $h_{f i}$. Because of precautions taken to maintain the cleanliness of the test facility's ammonia system (see Sec. 4), it is unlikely that foreign materials from this system could foul the tube outside surface. As far as water-side fouling is concerned, the water system was maintained under a nitrogen blanket since the initial filling. The water was continuously filtered during operation by a high-capacity filter located in a bypass line around the cold water pump. The extreme cleanliness of the system and the effectiveness of the corrosion inhibitor in scavenging oxygen and in preventing the deposit of hard calcium lead us to expect that the magnitude of the water-side fouling resistance is essentially zero. Thus it can be assumed that the last two terms in Eq. 7 are small enough to be neglected in determining $h_{0}$ and $h_{i}$ by the Wilson procedure.

The data obtained for the overall heat transfer coefficient, $U_{0}$, at the nominal heat duty of $3.2 \mathrm{million} B t u / h r$ and at different water flow rates are shown in Table 3 . From the plot of $U_{o}^{-1}$ versus $w_{c}-0.66$ the value of $U_{o}{ }^{-1}$ at the intercept $\mathrm{w}_{c}-0.66=0$ was determined (see Fig: 7 ). The straight line in Fig. 7 was obtained using the least-squares algorithm ( 1 inear regression), and the value of $\mathrm{U}_{\mathrm{o}}^{-1}$ at the intercept was found to be 0.0002540 $\mathrm{hr}^{\bullet} \mathrm{ft}^{2 .}{ }^{\circ} \mathrm{F} / \mathrm{Btu}$. The wall resistance term on the right side of $\mathrm{Eq}$. 7 was calculated using the following data for the Union Carbide condenser:

$$
\begin{aligned}
r_{0} & =0.0625 \mathrm{ft} \\
r_{i} & =0.0571 \mathrm{ft} \\
k & =92.5 \mathrm{Btu} / \mathrm{hr}^{\circ} \mathrm{ft}^{\circ}{ }^{\circ} \mathrm{F} *
\end{aligned}
$$

Table 3. Values of $U_{0}$ as a Function of Water Flow Rate

\begin{tabular}{lc}
\hline $\begin{array}{c}\mathrm{w}_{\mathrm{C}} \\
(\mathrm{gpm})\end{array}$ & $\left(\mathrm{Btu} / \mathrm{hr}^{\mathrm{U}_{\mathrm{ft}}}{ }^{\left.2 \cdot{ }^{\circ} \mathrm{F}\right)}\right.$ \\
\hline 1540 & 546 \\
1930 & 625 \\
2410 & 702 \\
3190 & 818 \\
3970 & 921 \\
5010 & 1014 \\
\hline
\end{tabular}

From this we obtained:

$$
\frac{\Delta \mathrm{rA}_{\mathrm{o}}}{\mathrm{kA}_{1 \mathrm{~m}}}=0.0000611 \mathrm{hr} \cdot \mathrm{ft}^{2 \cdot{ }^{\circ} \mathrm{F} / \mathrm{Btu}}
$$

Substitution of this into Eq. 7 gave a value of $h_{o}$ of $5180 \mathrm{Btu} / \mathrm{hr} \cdot \mathrm{ft}^{2}{ }^{\circ}{ }^{\circ} \mathrm{F}$, which is about two times the value calculated from the well-known Nusselt expression for condensation on unenhanced circular tubes. This value is also higher than that used by Union Carbide (around $3000 \mathrm{Btu} / \mathrm{hr} \cdot \mathrm{ft}^{2} \cdot{ }^{\circ} \mathrm{F}$ ) for design calculations. 4

\section{ॠFor aluminum alloy 3003 H112. Source: Aluminum Standards and Data,}




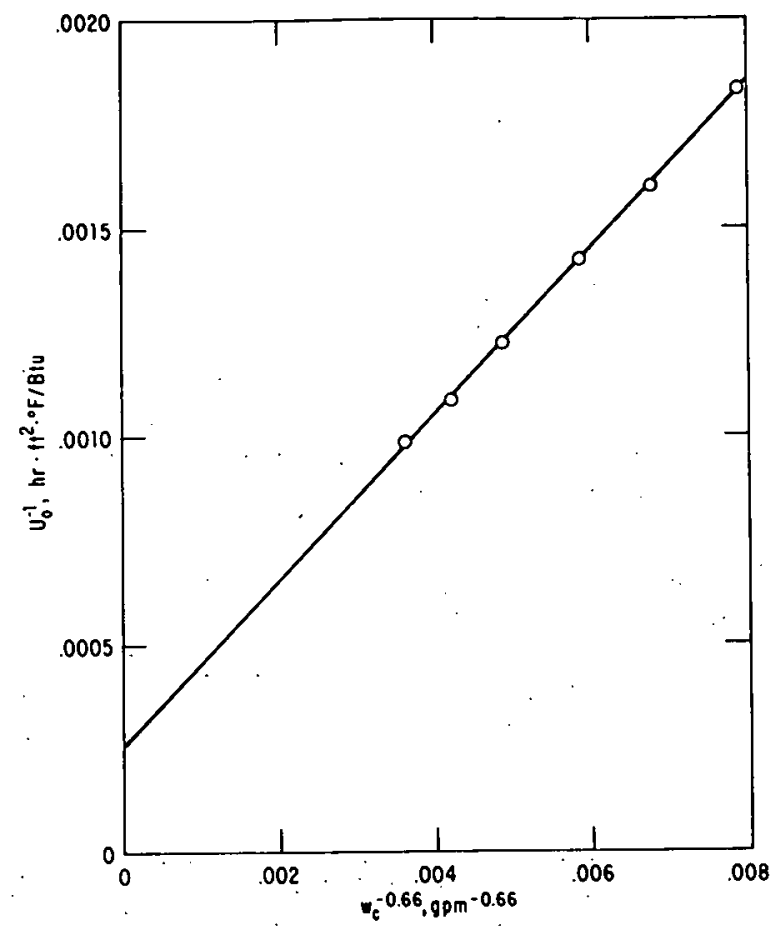

Fig. 7. Wilson Plot

With the value of $h_{0}$ known, we were able to calculate $h_{i}$ for each flow rate by using the $U_{o}$ values in Table 3 . The results are shown in Table 4 and plotted in Fig. 8. It can be seen that the values of $h_{i}$ are correlated well by the velocity power based on the Noranda equation and that they are very close to those predicted by the Noranda correlation (about 3\% higher). The equation for the straight line drawn through the data is $h_{i}=5.49 w_{c} 0.66$. For comparison, the Sieder-Tate correlation 5 is also plotted in Fig. 8. In the range of water flow rates tested, the $h_{i}$ values are 1.50 to 1.75 times larger than those predicted by the Sieder-Tate equation. These enhancement ratios, incidentally, are consistent with the 1.8 ratio of the actual wetted inside surface area (including fins) to the nominal inside surface area.

Before concluding this section, it should be mentioned that the individual coefficients as determined by the Wilson method are very sensitive to the choice of the exponent that expresses the dependence of $h_{i}$ on tube-side velocity. For example, using the conventional -0.8 power rather than -0.66 yields an ammonia-side

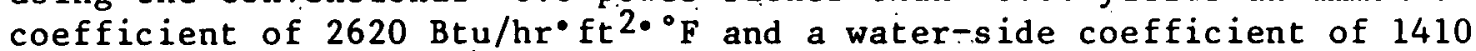

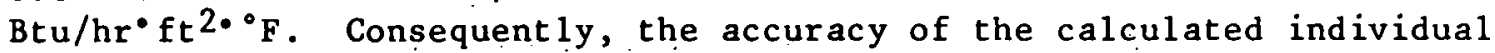
coefficients is strongly dependent on the accuracy of the velocity exponent in the correlation for $h_{i}$.

Table 4. Dependence of $h_{i}$ on Water Flow Rate

\begin{tabular}{|c|c|}
\hline $\begin{array}{l}\mathrm{w}_{\mathrm{c}} \\
(\mathrm{gpm})\end{array}$ & $\left(\right.$ Btu $/ \mathrm{hr} \cdot{ }^{\mathrm{h}_{\mathrm{i}}}{ }^{\left.2 .{ }^{\circ} \mathrm{F}\right)}$ \\
\hline 1540 & 697 \\
\hline 1930 & 809 \\
\hline 2410 & 937. \\
\hline 3190 & 1126 \\
\hline 3970 & 1302 \\
\hline 5010 & 1518 \\
\hline
\end{tabular}

\subsection{EFFECT OF HEAT DUTY ON U。}

The effect of heat duty on the overall heat transfer coefficient was investigated by comparing test results at heat duties of 2.4 million, 3.2 million, and $4.0 \mathrm{mill}$ ion $\mathrm{Btu} / \mathrm{hr}$. In Fig. 9 the effect of heat duty on $U_{0}$ is seen to be negligible. This implies that within the range tested heat duty has a negligible effect on the ammonia-side heat transfer coefficient. Furthermore, since condensate flow rate is proportional to heat duty, it follows that within the same range liquid loading does not significantly affect the ammonia-side heat transfer coefficient. 


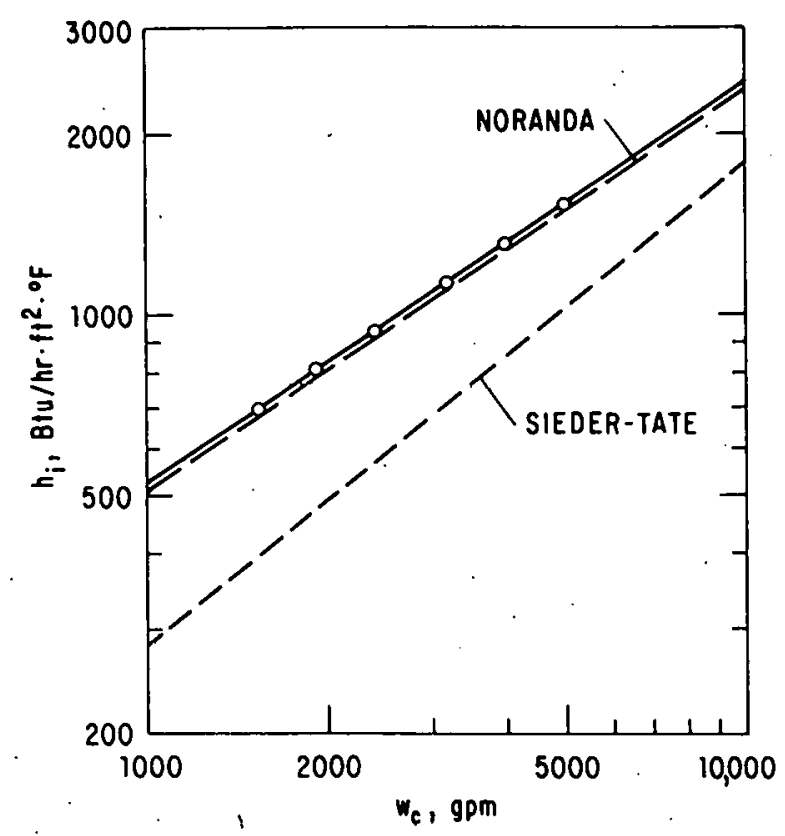

Fig. 8. Variation of Water-Side Coefficient with Water Flow Rate

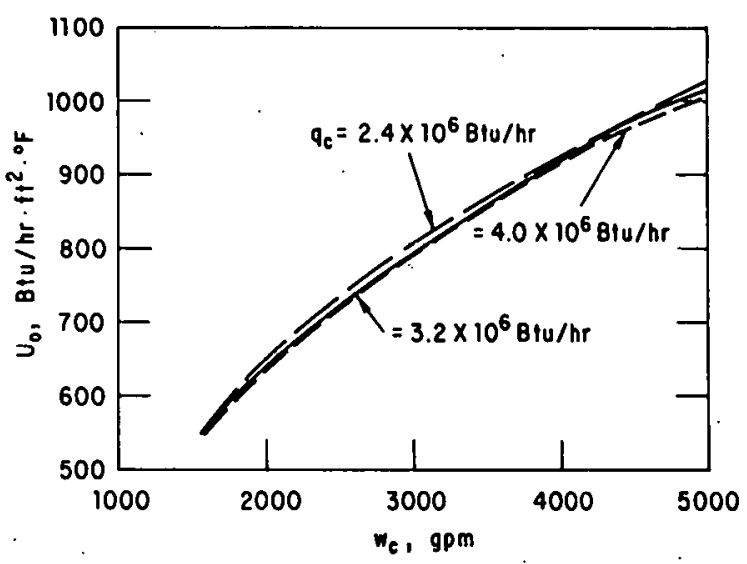

Fig. 9. Effect of Heat Duty on $\mathrm{U}_{\mathrm{o}}$

\subsection{EFFECT OF NONCONDENSABLES (VENTING) ON U。}

As noted in Sec. 4, when originally installed in the loop, the condenser had been checked for leaks, evacuated, back-filled with ammonia, and left under positive ammonia pressure. Some leaks had been observed when the condenser was subjected to system pressure, but these were corrected while the system was still under positive pressure. The condenser was not vented for removal of noncondensable gases immediately prior to the start of testing.

Blowdown of noncondensables was carried out, however, near the end of the test period. Two vent lines connected to the top of the condenser were opened for a period of two minutes. When data-taking resumed immediately afterward, an increase in $\mathrm{U}_{0}$ of $3 \%$ was observed. Since the scatter of the data was $\pm 1 \%$, this change, though small, is apparently real. The venting step was then repeated with no further improvement in performance.

\subsection{WATER-SIDE PRESSURE DROP}

Water-side pressure drops across the condenser were measured and recorded for all hard-copy data points. The results shown in Table 5 for each flow rate are averages of at least 20 values (covering all three heat duties).

It must be noted that there was considerable scatter in individual data points taken for the same operating conditions. This was especially pronounced at the lower water flow rates. The variability is apparently due to inadvertent location of the pressure taps in the water lines at places where

large pressure fluctuations occur. This gives rise to erratic instantaneous pressure readings.

\section{SUMMARY AND CONCLUSIONS}

An investigation has been made of the performance of the Union Carbide/ Linde enhanced-tube condenser under nominal design conditions -- specifically, a heat duty of $3.2 \mathrm{million} \mathrm{Btu} / \mathrm{hr}$, an inlet water temperature of $40^{\circ} \mathrm{F}$, and a 
Table 5. Water-Side Pressure Drop as a Function of Flow Rate

\begin{tabular}{cc}
\hline $\begin{array}{c}\text { Flow rate } \\
(\mathrm{gpm})\end{array}$ & $\begin{array}{c}\text { Average measured } \\
\text { pressure drop } \\
(\mathrm{psi})\end{array}$ \\
\hline 1516 & $0.6( \pm 0.4)$ \\
2398 & $1.1( \pm 0.5)$ \\
3198 & $1.8( \pm 0.6) \mathrm{a}$ \\
3993 & $2.7( \pm 0.6)$ \\
4965 & $3.9( \pm 0.6)$ \\
\hline
\end{tabular}

aThe predicted pressure drop is 2.0 psi (see Table 1). water flow rate of $3200 \mathrm{gpm}$. Under these conditions the value of the overall heat transfer coefficient

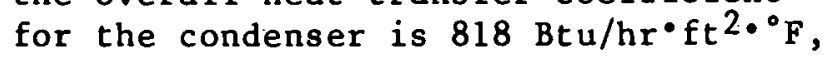
and the ammonia-side and water-side heat transfer coefficients are 5180 and $1130 \mathrm{Btu} / \mathrm{hr} \cdot \mathrm{ft}^{2 \cdot \circ} \mathrm{F}$, respectively. The water-side velocity is $5.0 \mathrm{ft} / \mathrm{sec}$ and the pressure drop is $1.8 \mathrm{psi}$.

The values for the ammonia-side and water-side heat transfer coefficients were obtained using the Wilson method, but with a velocity power of -0.66 conforming to the Noranda correlation for finned tubes. The ammonia-side heat transfer coefficient, $5180 \mathrm{Btu} /$ $\mathrm{hr} \cdot \mathrm{ft} 2{ }^{\circ} \mathrm{F}$, is about two times the value predicted by the Nusselt expression

for condensation on a smooth tube. The water-side heat transfer coefficient, 1130

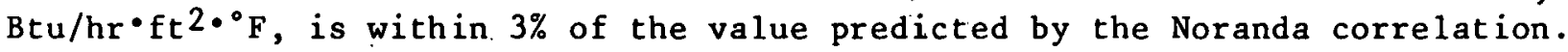

It was found that the individual coefficients as determined by the Wilson method are very sensitive to the choice of the exponent that expresses the dependence of $h_{i}$ on velocity. For example, using the conventional -0.8 power rather than the -0.66 power as in the Noranda correlation yields an ammonia-side coefficient of $2620 \mathrm{Btu} / \mathrm{hr} \cdot \mathrm{ft} 2 \cdot{ }^{\circ} \mathrm{F}$ and a water-side coefficient

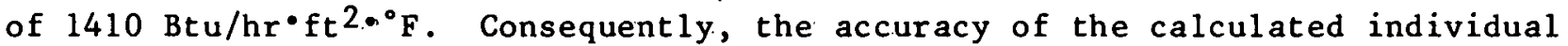
coefficients is strongly dependent on the accuracy of the exponent in the Noranda correlation:

Additional tests were conducted to study the effects of heat duty and noncondensables. The overall heat transfer coefficient was not affected when the heat duty was varied from $2.4 \mathrm{million}$ to $4.0 \mathrm{million} \mathrm{Btu} / \mathrm{hr}$. This implies that the effect of heat duty on the ammonia-side heat transfer coefficient is negligible within the range tested. Since condensate flow rate is proportional to heat duty, it also follows that within this range liquid loading does not. significantly affect the ammonia-side heat transfer coefficient. Apparently, small amounts of noncondensable gases were present throughout the testing, as evidenced by a $3 \%$ increase in the value of $\mathrm{U}_{0}$ following a purge at the conclusion of the test period. 
REFERENCES

1. Lewis, L.G., and N.F. Sather, OTEC Performance Tests of the Union Carbide Flooded-Bundle Evaporator, Argonne National Laboratory Report ANL/OTEC-PS-1 (Dec. 1978).

2. Hard-copy volumes of the test results are available from N.F. Sather.

3. The Noranda correlation was obtained from Dr. M. Jacobs of Union Carbide, Linde Division, Tonawanda, New York.

4. Communication with Union Carbide, Linde Division, Tonawanda, New York.

5. Sieder, E.N., and G.E. Tate, Heat Transfer and Pressure Drop of Liquids in Tubes, Industrial and Engineering Chemistry, 28(12): 1429-1435 (1936). 


\section{ACKNOWLEDGMENTS}

We wish to acknowledge the valuable contributions made by several persons at Argonne and elsewhere to this work. We thank Tony Thomas, manager of the OTEC power system development program at Argonne; Lloyd Lewis, Floyd Davis (of Globe Engineering), and Chester Brzegowy for their work on the design and construction of the test facility; Oscar Despe for assistance with the data-handling equipment; Bob Mandernack for supervising test facility operations; Christine Lemberg for editorial assistance; and Letitia Kaatz for typing the report. We also appreciate the helpful comments and suggestions made by Hans Fricke of Union Carbide Corporation, Ken Bell of Oklahoma. State University, and John Michel of Oak Ridge National Laboratory, all of whom reviewed the report prior to publication. Our thanks to all for their fine efforts. 
Distribution for ANL/OTEC-PS-2

Internal :

F.W. Ahrens

P. Bensen

C. Brzegowy

T.R. Bump

P.S. Chopra

J.M. Clinch

E.J. Croke

J.B. Darby

J.D. Ditmars
J.E. Draley

D.L. Hillis

J.S. Horowitz

A.B. Krisciunas

L.G. - Lewis

J.J. Lorenz

K.S. Macal

W.E. Massey

E.G. Pewitt

G.F. Popper
J.J. Roberts

G.S. Rosenberg

N.F. Sather (100)

A. Thomas

D.T. Yung

R.S. Zeno

ANL Contract File

ANL Libraries (5)

TIS Files (6)

\section{External:}

DOE-TIC, for distribution per UC-64 (386)

Manager, Chicago Operations Office

Chief, Chicago Patent Group

President, Argonne Universities Association

Energy and Environmental Systems Division Review Committee:

E.E. Angino, U. Kansas

R.E. Gordon, U. Notre Dame

W.W. Hogan, Harvard U.

L.H. Roddis, Jr., Charleston, S.C.

G.A. Rohlich, U. Texas at Austin

R:A. Schmidt, Electric Power Research Inst.

Components Technology Division Review Committee:

P.F. Cunniff, U. Maryland

W.E. Kessler, Commonwealth Associates

C.H. Kruger, Jr., St anford U.

N.J. Palladino, Pennsylvania State U.

N.C. Rasmussen, Massachusetts Inst. Technology

M.A. Schultz, Pennsylvania State U.

A. Sesonske, Purdue U.

H. Thielsch, ITT Grinnell Corp.

Y.C.L.S. Wu, U. Tennessee Space Inst.

H. Abelson, Mitre Corp.

Alfa-Laval Thermal, Inc.

J. Connel1

J.E. Yaffo

J.H. Anderson, Solar Sea Power, Inc:

K.J. Bell, Oklahoma State U.

A. Bergles, Iowa State U.

Carnegie-Mellon U.

J. Fetkovich

A. Lavi

R. Rothfus

A. Westerberg

F.H. Davis, Globe Engineering Co. 
Department of Energy

C. Castellano

R. Cohen

H. Coleman

S. Gronich (12)

J. Hartman

E.H. Kinelski

L. Lewis

H.H. Marvin

D.E. Neely

K. Read

W. Richards

W.G. Sherwood

Electrotechnical Laboratory, Japan

T. Homma

T. Kajikawa

Energy Technology and Engineering Center

P. Archbold

R. Glumace

A. Klein

F. Poucher

E.N. Ganic, U. Illinois

General Electric Co.

R. Hindle

M.G. Olmsted

J.H. Gibbons, Office of Technology Assessment, U.S. Congress G.K. Hart, DSS Engineers, Inc.

Johns Hopkins U./Applied Physics Laboratory

R. Cusick

J. Funk

J. George

J. Keirsey

R. Makofski

D. Richards

H. Kamogawa, Toshiba Corp., Japan

D.E. Kash, USGS

J. Knudsen, Oregon State U.

Lockheed Missiles \& Space Co.

R. Cont i

M. Leitner

B. Messinger

F. Naef

W.L. Owens

L. Trimble

P. Marto, Naval Post Graduate School

R.A. Meyer, The OTEC Liaison

Oak Ridge National Laboratory

R. Lyon

J. Miche 1

R. Murphy

L. Perrigo, Pacific Northwest Laboratories

Rand Corp.

C. Gazley

R. Pei 
Rockwel1 International

M.T. Constantine

W.R. Wagner

D. Wright

C.M. Sabin, Geoscience, Ltd.

J. Sangiovani, United Technologies Research Center

D. Sasscer, U. Puerto Rico

J. Sladky, Value Engineering

Solar Energy Research Inst.

F. Kreith

B. Shelpuk

Trane Co.

D. Ashworth

H. Foust

TRW

J. Denton

R. Douglass

J. Kaellis

E. Snyder

A. Sprouse

H. Uehara, Saga U., Japan

Union Carbide Corp.
A. Czikk
H. Fricke
P. O'Neill

U. Hawaii

E.K. Noda

J. Shupe

H.J. White

P. Yuen

U. Massachusetts

W. Heronemus

J. McGowan

R. Webb, Pennsylvania State U.

Westinghouse Electric Corp.

E. Barsness

J. Gertz

R.E. Williams, III, PRC Energy Analysis Co.

J.F. Yampolsky, General Atomic Co. 